\title{
PENGARUH PENDEKATAN OPEN-ENDED TERHADAP KEMAMPUAN BERPIKIR KREATIF MATEMATIS MAHASISWA PGSD
}

\author{
Taufiqulloh Dahlan $^{1}$, M. Nurhadi ${ }^{2}$, dan Siti Maryam Rohimah ${ }^{3}$ \\ Dosen PGSD FKIP UNPAS

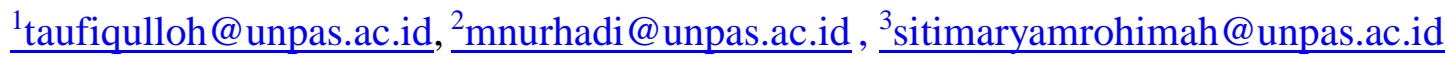

\begin{abstract}
ABSTRAK
Penelitian ini bertujuan untuk mengkaji apakah pencapaian dan peningkatan kemampuan berpikir kreatif matematis antara mahasiswa yang menggunakan pendekatan open-ended lebih baik dari pada mahasiswa yang menggunakan pembelajaran ekspositori. Penelitian ini merupakan penelitian quasi eksperimen karena pada penelitian ini subjek tidak dikelompokkan secara acak, tetapi peneliti menerima keadaan subjek apa adanya, dengan desain nonequivalent pretest-postest control group design. Populasi penelitian ini adalah seluruh mahasiswa program studi PGSD dari satu diantara perguruan tinggi yang berada di Jawa Barat dengan sampel terdiri dari 2 kelas. Kelas pertama merupakan kelas eksperimen yang memperoleh pembelajaran matematika menggunakan pendekatan open-ended dan kelas kedua merupakan kelas kontrol yang memperoleh pembelajaran ekspositori. Pengambilan data menggunakan pretest, posttest dan rataan gain ternormalisasi antara kedua kelompok sampel. Analisis data dilakukan terhadap nilai pretest, posttest dan rataan gain ternormalisasi antara kedua kelompok sampel dengan menggunakan uji t untuk mengetahui perbedaan kemampuan berpikir kreatif matematis. Lembar observasi dideskripsikan menggunakan persentase untuk menelaah aktivitas mahasiswa dan dosen selama perkuliahan menggunakan pendekatan open-ended. Diperoleh hasil bahwa pencapaian dan peningkatan kemampuan berpikir kreatif matematis antara mahasiswa yang menggunakan pendekatan open-ended lebih baik dari pada mahasiswa yang menggunakan pendekatan ekspositori. Analisis dari lembar observasi mahasiswa dan dosen diperoleh pembelajaran matematika menggunkan pendekatan open-ended terlaksana dengan baik.
\end{abstract}

Kata Kunci: Open-ended dan berpikir kreatif matematis. 


\begin{abstract}
This study aims to examine whether the achievement and improvement of the ability of mathematical creative thinking among students using the open-ended approach is better than the students who use conventional learning. This research is a quasi experimental research because in this study the subject is not randomly grouped, but the researcher accepts the subject state as it is, with the nonequivalent design pretest-postest control group design. The population of this study is all students of Primary School Teacher Education study program from one of the universities located in West Java with a sample consisting of 2 classes. The first class is an experimental class that obtains learning mathematics using an open-ended approach and the second class is a control class that obtains conventional learning. Data were collected using pretest, posttest and normalized gain flows between the two sample groups. Data analysis was performed on pretest, posttest and normalized gain values between the two sample groups using t-test to determine the difference of mathematical creative ability. The observation sheet is described using percentages to review student and lecturer activities during lectures using an open-ended approach. The results obtained that the achievement and improvement of the ability of mathematical creative thinking between students using the open-ended approach is better than the students using the conventional approach. Analysis of student and lecturer observation sheets obtained mathematics learning using open-ended approach well done.
\end{abstract}

Keywords: Open-ended and creative thinking mathematically. 


\section{A. PENDAHULUAN}

Indonesia sebagai negara yang berkembang, terus berupaya untuk meningkatkan kualitas sumber daya manusia melalui pendidikan nasional. Tujuan pendidikan nasional adalah meningkatkan kualitas manusia Indonesia yaitu manusia yang beriman dan bertaqwa kepada Tuhan Yang Maha Esa, berbudi pekerti luhur, berkepribadian mandiri, maju, tangguh, cerdas, kreatif, produktif serta sehat jasmani dan rohani. Sesuai dengan tujuan pendidikan nasional tersebut dan selaras dengan tuntutan zaman maka peningkatan kualitas pendidikan merupakan kebutuhan yang sangat mendesak.

Di dalam pelaksanaan proses perkuliahan dibutuhkan komunikan (dosen), metode pembelajaran, alat bantu untuk menyampaikan (media), urutan yang logis, dan suasana seluruh kegiatan (sistem). Dalam perkuliahan, peran dosen sangatlah penting untuk menciptakan suatu kondisi lingkungan yang menyenangkan sehingga dapat mempengaruhi pembinaan dan meningkatkan reativitas dalam kegiatan perkuliahan. Tetapi, merancang perkuliahan matematika yang sesuai dengan tujuan tidaklah mudah. Banyak dijumpai mahasiswa yang mempunyai nilai rendah dalam sejumlah mata kuliah, termasuk mata kuliah matematika.

Menurut Harris (Mina, 2009:80) banyak pemikiran yang dilakukan dalam perkuliahan matematika formal hanya menekankan pada keterampilan analisis mengajarkan bagaimana mahasiswa memahami klaim-klaim, mengikuti atau menciptakan suatu alasan logis, menggambarkan jawaban, mengeliminasi jalur yang tak benar dan fokus pada jalur yang benar. Sedangkan jenis yang lainnya yaitu berpikir kreatif yang fokus pada penggalian ide-ide, memunculkan kemungkinan-kemungkinan mencari banyak jawaban benar daripada satu jawaban kurang diperhatikan.

Rendahnya kemampuan berpikir kreatif juga dapat berimplikasi pada rendahnya prestasi mahasiswa. Menurut Wahyudin (2007:223) di antara penyebab rendahnya pencapaian mahasiswa dalam mata kuliah matematika adalah proses perkuliahan yang belum optimal. Dalam proses perkuliahan umumnya dosen sibuk sendiri menjelaskan materi, media dan lain-lain yang telah dipersiapkannya. Demikian juga mahasiswa sibuk sendiri menjadi penerima informasi yang baik. Akibatnya mahasiswa hanya mencontoh apa yang dikerjakan dosen, tanpa makna dan pengertian sehingga dalam menyelesaikan soal mahasiswa beranggapan cukup dikerjakan seperti apa yang dicontohkan. Hal tersebut menyebabkan mahasiswa kurang memiliki kemampuan menyelesaikan masalah dengan alternatif lain dapat disebabkan karena mahasiswa 
kurang memiliki kemampuan fleksibilitas yang merupakan komponen utama kemampuan berpikir kreatif. Fakta menunjukkan kurangnya perhatian terhadap kemampuan berpikir kreatif dalam matematika beserta implikasinya, dengan demikian adalah perlu untuk memberikan perhatian lebih pada kemampuan ini dalam mata kuliah matematika saat ini.

Tabel 1.

Pencapaian Indikator Kemampuan Berpikir Kreatif Matematis

\begin{tabular}{clc}
\hline No. & Indikator Kemampuan Berpikir Kreatf Matematis & Pencapaian \\
\hline 1. & $\begin{array}{l}\text { Kelancaran, kelancaran adalah kemampuan menjawab } \\
\text { masalah matematika secara tepat. }\end{array}$ & $40,71 \%$ \\
2. $\begin{array}{l}\text { Keluwesan, keluwesan adalah kemampuan menjawab } \\
\text { masalah matematika, melalui cara yang tidak baku }\end{array}$ & $30,71 \%$ \\
& $\begin{array}{l}\text { Keaslian, keaslian adalah kemampuan menjawab } \\
\text { masalah matematika dengan menggunakan bahasa, } \\
\text { cara, atau idenya sendiri }\end{array}$ & $41,43 \%$ \\
& $\begin{array}{l}\text { Elaborasi,elaborasi adalah kemampuan memperluas } \\
\text { jawaban masalah, memunculkan masalah baru atau }\end{array}$ & $37,86 \%$ \\
\hline
\end{tabular}

Sumber : Studi pendahuluan di salah satu PGSD swasta di Kota Bandung 2016

Rendahnya kemampuan berpikir kreatif matematis mahasiswa terjadi karena dalam pelaksanaan perkuliahan matematika kita belum mampu menafsirkan kebijakan kurikulum sepenuhnya. Kemampuan berpikir kreatif matematis, walaupun secara eksplisit diamanatkan dalam kurikulum namun dalam pelaksanaannya metode pembelajaran dan bahan ajar yang digunakan tidak fokus pada pengembangan kemampuan berpikir kreatif matematis, sehingga juga kurang memfasilitasi mahasiswa dalam melakukan berpikir kreatif matematis. Seharusnya dalam mendesain perkuliahan memegang prinsip kesesuaian antara model, strategi, pendekatan, atau metode pembelajaran yang digunakan dengan materi perkuliahan serta mampu memfasilitasi kemampuan mahasiswa. Hal ini sesuai dengan yang dikemukakan Trianto (2011:48) bahwa dalam dalam memilih suatu pendekatan perkuliahan harus memiliki pertimbangan-pertimbangan. Diduga, perkuliahan matematika yang paling memungkinkan untuk meningkatkan kemampuan berpikir kreatif matematis adalah menerapkan pembelajaran menggunakan pendekatan open-ended.

Hal ini sesuai dengan yang dinyatakan Mahmudi (2015:7) penggunaan masalah dengan menggunakan pendekatan open-ended menjadi sangat relevan dalam perkuliahan matematika dengan maksud untuk mengembangkan kemampuan berpikir kreatif matematis sekaligus menstimulasi mahasiswa untuk megembangkan ide-ide matematikanya karena hal demikian tidak akan terjadi apabila dalam perkuliahan 
matematika menggunakan satu cara yang sama untuk menemukan suatu solusi tunggal dari masalah yang diberikan. Jawaban dan strategi yang tunggal terhadap suatu masalah kurang mendorong mahasiswa untuk saling berkomunikasi karena masing-masing mahasiswa akan lebih memfokuskan diri pada strategi mereka sendiri. Oleh karena itu, melalui pendekatan open-ended mahasiswa memiliki peluang aktivitas yang cukup untuk mengkomunikasikan ide, situasi, dan relasi matematik dengan gambar, grafik, atau aljabar mengunakan cara dan bahasanya sendiri.

\section{B. KAJIAN TEORITIS}

\section{Pendekatan Open-ended}

Swada (2007:23) mengemukakan pembelajaran menggunakan pendekatan openended, dosen memberikan suatu situasi masalah kepada mahasiswa yang solusi masalah tersebut dapat diperoleh dengan berbagai cara. Selanjutnya, Shimada (2007:32) masalah yang diformulasikan memiliki banyak jawaban benar disebut masalah tak lengkap (incomplete) atau masalah terbuka (open ended). Secara umum masalah openended adalah masalah tak lengkap yang memiliki banyak cara untuk menemukan satu atau banyak penyelesaian.

Suatu masalah akan kehilangan sifat keterbukaannya apabila hanya ada satu cara dalam menjawab permasalahan yang mungkin untuk masalah tersebut. Menurut Becker dan Epstein (dalam Wijaya, 2012:74), aspek keterbukaan pada masalah terbuka dapat diklasifikasikan ke dalam tiga tipe, yaitu: 1) terbuka proses penyelesaiannya, yakni soal itu memiliki beragam cara penyelesaian. Jenis Soal semacam ini masih memungkinkan memiliki satu solusi tunggal, 2) terbuka hasil akhirnya, yakni soal itu memiliki banyak jawab yang benar, dan 3) terbuka pengembangan lanjutannya, yakni ketika mahasiswa telah menyelesaikan suatu masalah, selanjutnya mereka dapat mengembangkan soal baru dengan mengubah syarat atau kondisi pada soal yang telah diselesaikan.

Secara garis besar langkah-langkah pembelajaran dengan pendekatan Openended berdasarkan pendapat Swada (2007:24) dan Hashimoto (2007:28) serta Suherman, dkk (2001:38) dibagi menjadi dua tahap. Tahap Pertama: 1) Memberi masalah yang bersifat terbuka, 2) mengeksplorasi masalah, dalam mengeksplorasi masalah waktu yang diberikan dibagi menjadi dua bagian. Bagian pertama: Mahasiswa bekerja secara individu untuk menyelesaikan masalah. Mahasiswa diberi kebebasan untuk menyelesaikan masalah dengan berbagai cara. Bagian Kedua: Mahasiswa bekerja secara berkelompok untuk mendiskusikan hasil pekerjaan individunya. Pada Tahap 
Kedua, 3) Merekam respon Mahasiswa, 4) pembahasan respon-respon Mahasiswa yang beragam yang dipeoleh dari soal terbuka dan terakhir 5) meringkas apa yang dipelajari.

\section{Kemampuan Berpikir Kreatif Matematis}

Secara singkat berpikir kreatif dapat dikatakan sebagai pola berpikir yang didasarkan pada suatu cara yang mendorong kita untuk menghasilkan produk yang kreatif. Masih banyak definisi yang berkaitan dengan kreatifitas, namun pada intinya ada persamaan antara definisi-definisi tersebut, yaitu kemampuan berpikir kreatif merupakan kemampuan seseorang untuk melahirkan sesuatu yang baru, baik berupa gagasan maupun karya nyata yang relatif berbeda dengan yang telah ada sebelumnya. Sesuatu yang baru disini tidak harus berupa hasil/ ciptaan yang benar-benar baru walaupun hasil akhirnya mungkin akan tampak sebagai sesuatu yang baru, tetapi dapat berupa hasil penggabungan dua atau lebih konsep-konsep yang sudah ada.

Menurut Hassoubah (2004:56), kriteria produk yang kreatif tidak bergantung kepada satu sifat saja, yaitu ide yang baru, tetapi melibatkan banyak komponen, yang meliputi:

a) Berpikir kreatif melibatkan sisi estetik dan standar praktis.

b) Berpikir kreatif bergantung pada perhatian terhadap tujuan dan hasil.

c) Berpikir kreatif lebih banyak bergantung kepada mobilitas daripada kelancaran.

d) Berpikir kreatif tidak hanya obyektif tapi juga subyektif.

e) Berpikir kreatif lebih banyak bergantung kepada motivasi ekstrinsik.

Evans (2009:98) mengemukakan bahwa berpikir kreatif terdeteksi dalam empat unsur yaitu: Kepekaan (Sensitivity), Kelancaran (Fluency), Keluwesan (Flexibility), dan Keaslian (Originality). Kepekaan terhadap suatu situasi masalah menyangkut kemampuan mengidentifikasi adanya masalah, mampu membedakan fakta yang tidak relevan dengan masalah, termasuk membedakan konsep-konsep yang relevan mengenai masalah yang sebenarnya. Kepekaan ini termasuk juga apa yang dirasakan seseorang sehubungan dengan masalah yang diidentifikasi, misalnya konsep yang terkait, strategi yang sesuai untuk menyelesaikan masalah itu. Kepekaan akan muncul lebih jelas jika ada semacam rangsangan yang disediakan dalam masalah serta tantangan yang diberikan oleh guru.

Kepekaan dapat memicu individu untuk meneruskan upaya untuk melakukan kegiatan obsevasi, explorasi sehingga dapat memunculkan gagasan-gagasan. Kelancaran merupakan kemampuan untuk membanguan banyak ide secara mudah. 
Kelancaran dalam memunculkan gagasan atau pertanyaan yang beragam serta menjawabnya, ataupun merencanakan dan menggunakan sebagai strategi penyelesaian pada saat menghadapi masalah yang rumit. Keluwesan mengacu pada kemampuan untuk membanguan ide yang beragam. Keluwesan dapat dipandang sebagai suatu variasi yang menunjukkan kekayaan ide dan usaha dari yang bersangkutan dalam membangun gagasan menuju pada solusi yang diharapkan. Keaslian adalah kemampuan untuk menghasikan ide-ide yang tidak umum dan menyelesaikan masalah dengan cara yang tidak umum. Keaslian ini muncul dalam berbagai bentuk, dari yang sederhana atau yang informal untuk kemudian dapat dikembangkan menjadi lebih lengkap.

Sementara itu, menurut Williams (2007:15), bahwa kemampuan yang berkaitan dengan berpikir kreatif ini ada delapan kemampuan, empat dari ranah kognitif dan empat dari ranah afektif. Berikut ini empat kemampuan dari ranah kognitif disebutkan secara lengkap oleh Williams yaitu sebagai berikut:

\section{Berpikir lancar}

a. Menghasilkan banyak gagasan atau jawaban yang relevan.

b. Arus pemikiran lancar.

2. Berpikir luwes

a. Menghasikan gagasan-gagasan yang bervariasi

b. Mampu mengubah cara atau pendekatan

c. Arah pemikiran yang berbeda.

\section{Orisinal}

Memberikan jawaban yang tidak lazim, yang lain dari yang lain yang jarang diberikan kebanyakan orang.

\section{Terperinci}

a. Mengembangkan, menambah, memperkaya suatu gagasan.

b. Memperinci dengan detail.

c. Memperluas suatu gagasan.

Berdasarkan latar belakang yang telah dipaparkan diatas, maka rumusan masalah dalam penelitian ini sebagai berikut:

1. Apakah pencapaian kemampuan berpikir kreatif matematik antara siswa yang menggunakan pendekatan open-ended lebih baik dari pada siswa yang menggunakan pembelajaran ekspositori? 
2. Apakah peningkatan kemampuan berpikir kreatif matematik antara siswa yang menggunakan pendekatan open-ended lebih baik dari pada siswa yang menggunakan pembelajaran ekspositori?

\section{METODE PENELITIAN}

Penelitian ini merupakan penelitian quasi eksperimen karena pada penelitian ini subjek tidak dikelompokkan secara acak, tetapi peneliti menerima keadaan subjek apa adanya (Ruseffendi, 2008:27). Desain dalam penelitian ini adalah desain kelompok nonequivalent pretest-postest control group (Ruseffendi, 2008:29).

Penelitian ini dilakukan satu diantara program studi PGSD yang ada di Perguruan Tinggi Jawa Barat. Populasi dalam penelitian ini adalah seluruh mahasiswa semester VI satu diantara program studi PGSD yang ada Jawa Barat yang ada di semester genap pada tahun ajaran 2016/2017. Pengambilan sampel dilakukan dengan teknik purposive sampling, yaitu teknik penentuan sampel dengan pertimbangan tertentu (Sugiyono, 2008:54).

Penelitian ini menggunakan instrumen penelitian, yaitu instrumen tes. Instrumen tes berupa tes kemampuan berpikir kritis matematis. Data dalam penelitian ini akan dikumpulkan melalui tes kemampuan berpikir kritis matematis terhadap pendekatan open-ended. Data yang berkaitan dengan kemampuan kemampuan berpikir kritis matematis mahasiswa dikumpulkan melalui tes (pretest) dan tes (postest). Keseluruhan instrumen tersebut telah divalidasi terlebih dahulu.

Beberapa soal kemampuan berpikir kreatif matematis yang diteskan:

1. Intan mempunyai kawat sepanjang $108 \mathrm{~cm}$. Kawat tersebut digunakan untuk membuat tiga buah kerangka kubus dengan ukuran yang berbeda. Tentukan berbagai kemungkinan ukuran rusuk dari ketiga kubus tersebut sehingga kawat habis terpakai. Jelaskan jawabanmu (minimal 3)!

2. Hitunglah volume bangun berikut (minimal menggunakan 2 cara)!

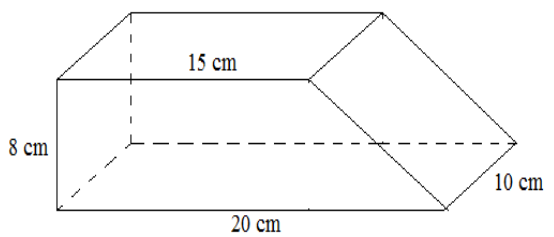


3. Buatlah minimal tiga jaring-jaring dari bangun berikut!

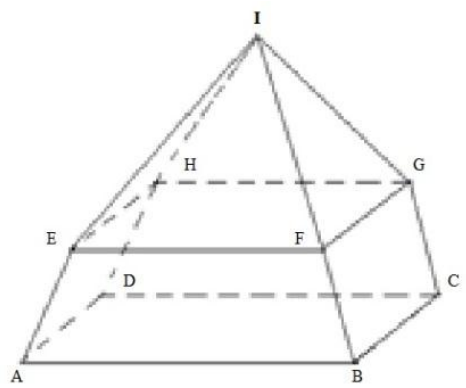

4. Suatu balok ABCD.EFGH berukuran panjang $12 \mathrm{~cm}$ dan tinggi $4 \mathrm{~cm}$. Tentukan luas bidang-bidang balok tersebut jika luas permukaannya $352 \mathrm{~cm}^{2}$ !

Hipotesis:

1. Ho: Pencapaian kemampuan berpikir kreatif matematis mahasiswa yang mendapat pembelajaran dengan pendekatan open-ended tidak lebih baik dari pada siswa yang mendapat pembelajaran ekspositori

Ha: Pencapaian kemampuan berpikir kreatif matematis mahasiswa yang mendapat pembelajaran dengan pendekatan open-ended lebih baik dari pada siswa yang mendapat pembelajaran ekspositori

2. Ho: Peningkatan kemampuan berpikir kreatif matematis mahasiswa yang mendapat pembelajaran dengan pendekatan open-ended tidak lebih baik dari pada siswa yang mendapat pembelajaran ekspositori

Ha: Peningkatan kemampuan berpikir kreatif matematis mahasiswa yang mendapat pembelajaran dengan pendekatan open-ended tidak lebih baik dari pada siswa yang mendapat pembelajaran ekspositori

Kriteria pengujian Hipotesis:

Tolak Ho jika $\frac{p \text {-value (sig.) }}{2}<\alpha$

\section{HASIL DAN PEMBAHASAN}

\section{Analisis Pretest}

Sebelum dilakukan uji perbedaan rerata terlebih dahulu dilakukan uji normalitas dan homogenitas variansi kedua kelompok data. Hasil uji normalitas menggunakan uji Shapiro-Wilk menyatakan data pretest kemampuan berpikir kreatif matematis Mahasiswa pada masing-masing kelompok data adalah berdistribusi normal. Dari hasil uji homogenitas menggunakan uji Levene data pretest kemampuan berpikir kreatif matematis variansinya homogen. 
Selanjutnya untuk mengetahui perbedaan rerata kedua kelompok data pretest kemampuan berpikir kreatif matematis digunakan uji t. Ringkasan statistik deskriptif data prestest kemampuan berpikir kreatif matematis dan hasil uji perbedaan rerata data pretest secara berurutan disajikan pada Tabel 2 dan Tabel 3.

Tabel 2.

Statistik Deskriptif Data Pretest Kemampuan Berpikir Kreatif Matematis

\begin{tabular}{cccc}
\hline $\begin{array}{c}\text { Kem. Brpkr. Kreatif } \\
\text { Matematika }\end{array}$ & N & Mean & Std. Deviasi \\
\hline Eks & 35 & 48,77 & 9,644 \\
Kontrol & 35 & 45,66 & 9,194 \\
\hline
\end{tabular}

Berdasarkan statistik deskriptif data pretest secara umum menunjukkan bahwa mean data pretest kemampuan berpikir kreatif matematis Mahasiswa sebelum diberi perlakukan pada kelompok eksperimen lebih besar dari pada kelompok kontrol, namun perbedaan mean tersebut terlihat sangat kecil. Melalui uji t dapat juga diketahui apakah perbedaan tersebut signifikan.

Tabel 3.

Uji Perbedaan Rerata Data Pretest Kemampuan Berpikir Kreatif Matematis

\begin{tabular}{ccccc}
\hline $\begin{array}{l}\text { Kem.Brpkr. } \\
\text { Kreatif Matematika }\end{array}$ & T & Dk & P-value/ Sig. & $\boldsymbol{H}_{\mathbf{0}}$ \\
\hline Equal variances assumed & 1,383 & 68 & 0.171 & Diterima \\
\hline$H_{0}$ : Tidak terdapat perbedaan rerata antar kedua kelompok &
\end{tabular}

Berdasarkan Tabel 3 dapat dilihat bahwa nilai probabilitas (sig.) sebesar 0,171 $>0,05$ sehingga hipotesis nol diterima. Hasil ini menunjukkan tidak terdapat perbedaan yang signifikan antara rerata skor pretest kelompok eksperimen dengan kelompok kontrol. Artinya kemampuan awal Berpikir Kreatif Matematis mahasiswa sebelum diberi perlakuan tidak berbeda secara sehingga persyaratan untuk dilakukannya suatu eksperimen dapat dipenuhi.

\section{Analisis Pencapaian}

Data pencapaian Kemampuan Berpikir Kreatif Matematis diperoleh dari skor postest kemampuan Berpikir Kreatif Matematis. Dari hasil uji normalitas menggunakan uji Shapiro-Wilk diperoleh hasil bahwa kedua data posttest kemampuan Berpikir Kreatif Matematis adalah berdistribusi normal. Dari hasil uji homogenitas menggunakan uji Levene, data posttest kemampuan Berpikir Kreatif Matematis variansinya homogen. Untuk mengetahui perbedaan rerata kedua kelompok data pencapaian Kemampuan Berpikir Kreatif Matematis digunakan uji t. Ringkasan 
statistik deskriptif data pencapaian kemampuan komunikasi matematik dan hasil uji perbedaan rerata data pencapaian secara berurutan disajikan pada Tabel 4 dan Tabel 5 .

Tabel 4.

Statistik Deskriptif Data Pencapaian Kemampuan Berpikir Kreatif Matematis

\begin{tabular}{cccc}
\hline $\begin{array}{c}\text { Kem. Brpkr. Kreatif } \\
\text { Matematika }\end{array}$ & N & Mean & Std. Deviasi \\
\hline Eks & 35 & 76,23 & 11,309 \\
Kontrol & 35 & 57,14 & 9,456 \\
\hline
\end{tabular}

Berdasarkan statistik deskriptif data pencapaian secara umum menunjukkan bahwa mean data pencapaian Kemampuan Berpikir Kreatif Matematis mahasiswa pada kelompok eksperimen lebih baik dari pada kelompok kontrol. Melalui uji t dapat juga diketahui apakah perbedaan tersebut signifikan.

Berdasarkan Tabel 5 dari uji t menghasilkan nilai probabilitas (sig.) 0,000 pada uji dua pihak maka untuk uji satu pihak nilai probabilitas (sig.) sebesar 0,000 $<0,05=$ sehingga hipotesis nol ditolak. Artinya pencapaian Kemampuan Berpikir Kreatif Matematis mahasiswa yang mendapat pembelajaran dengan pendekatan openended lebih baik dari pada mahasiswa yang mendapat pembelajaran ekspositori. Hasil ini menunjukkan terdapat perbedaan pencapaian yang signifikan antara kelompok eksperimen dengan kelompok kontrol.

Tabel 5.

Uji perbedaan rerata dalam pencapaian Kemampuan Berpikir Kreatif Matematis

\begin{tabular}{ccccc}
\hline $\begin{array}{c}\text { Kem. Brpkr. Kreatif } \\
\text { Matematika }\end{array}$ & T & Df & $\begin{array}{c}\text { P-value/ } \\
\text { Sig. }\end{array}$ & $\boldsymbol{H}_{\mathbf{0}}$ \\
\hline Equal variance assumed & 7,660 & 68 & .000 & Ditolak \\
\hline
\end{tabular}

Nilai mean pencapaian Kemampuan Berpikir Kreatif Matematis pada kelas eksperimen adalah 76,23 dan kelas kontrol adalah 57,14.

\section{Analisis Peningkatan}

Data peningkatan Kemampuan Berpikir Kreatif Matematis diperoleh melalui skor peningkatan (N-Gain) Kemampuan Berpikir Kreatif Matematis mahasiswa. Dari hasil uji normalitas data N- Gain Kemampuan Berpikir Kreatif Matematis mahasiswa menggunakan uji Shapiro-Wilk diperoleh hasil bahwa kedua data tersebut adalah berdistribusi normal. Dari hasil uji homogenitas menggunakan uji Levene, data $N$-Gain Kemampuan Berpikir Kreatif Matematis variansinya tidak homogen.

Selanjutnya untuk mengetahui ada atau tidaknya perbedaan rerata kedua kelompok data peningkatan Kemampuan Berpikir Kreatif Matematis digunakan uji t‘. 
Ringkasan statistik deskriptif data peningkatan Kemampuan Berpikir Kreatif Matematis dan hasil uji perbedaan rerata data peningkatan secara berurutan disajikan pada Tabel 5 dan 6 .

Berdasarkan statistik deskriptif data peningkatan secara umum menunjukkan bahwa mean data peningkatan Kemampuan Berpikir Kreatif Matematis mahasiswa pada kelompok eksperimen adalah 0,5114 artinya mean peningkatan kelompok eksperimen yang memperoleh pembelajaran dengan pendekatan open-ended dapat diinterpretasikan sedang. Sedangkan mean data peningkatan Kemampuan Berpikir Kreatif Matematis mahasiswa pada kelompok kontrol adalah 0,2069 artinya mean gain kelompok kontrol yang memperoleh pembelajaran ekspositori dapat diinterpretasikan rendah (Hake dalam Meltzer dalam Hutagaol, 2009). Mean data peningkatan Kemampuan Berpikir Kreatif Matematis mahasiswa pada kelompok eksperimen lebih besar dari pada kelompok kontrol. Melalui uji t' dapat juga diketahui apakah perbedaan peningkatan tersebut signifikan.

Tabel 6.

Statistik Deskriptif Data Peningkatan Kemampuan Berpikir Kreatif Matematis

\begin{tabular}{cccc}
\hline $\begin{array}{c}\text { Kem. Brpkr. Kreatif } \\
\text { Matematika }\end{array}$ & N & Mean & Std. Deviasi \\
\hline Eks & 35 &, 5114 &, 25488 \\
Kontrol & 35 &, 2069 &, 13217 \\
\hline
\end{tabular}

Tabel 7.

Uji Perbedaan Rerata Data Peningkatan Kemampuan Berpikir Kreatif Matematis

\begin{tabular}{ccccc}
\hline $\begin{array}{c}\text { Kem. Brpkr. Kreatif } \\
\text { Matematika }\end{array}$ & T & Df & $\begin{array}{c}\text { P-value/ } \\
\text { Sig. }\end{array}$ & $\boldsymbol{H}_{\mathbf{0}}$ \\
\hline Equal variance assumed & 6,276 & 51,025 & 0.000 & Ditolak \\
\hline
\end{tabular}

Selanjutnya, berdasarkan Tabel 7 dari uji t‘ menghasilkan nilai probabilitas (sig.) 0,000 pada uji dua pihak maka untuk uji satu pihak nilai probabilitas (sig.) sebesar sebesar $0,000<0,05=$ sehingga hipotesis nol ditolak. Artinya peningkatan Kemampuan Berpikir Kreatif Matematis mahasiswa yang mendapat pembelajaran dengan pendekatan open-ended lebih baik dari pada mahasiswa yang mendapat pembelajaran ekspositori. Hasil ini menunjukkan terdapat perbedaan peningkatan yang signifikan antara kelompok eksperimen dengan kelompok kontrol. 


\section{Analisis Lembar Observasi}

Hasil persentase observasi aktivitas guru dalam melaksanakan pembelajaran menggunakan pendekatan open-ended pada seluruh pertemuan adalah 82,22\%. Dapat disimpulkan bahwa pembelajaran dilakukan guru selama menerapkan pendekatan open-ended terlaksana dengan baik.

Hasil observasi aktivitas mahasiswa dalam mengikuti pembelajaran pada menggunakan pendekatan open-ended pada seluruh pertemuan adalah 82, 22\%. Dapat disimpulkan bahwa aktivitas yang dilakukan mahasiswa selama mengikuti pembelajaran matemtika melalui pendekatan open-ended terlaksana dengan baik. Artinya keberhasilan peningkatan dan pencapaian Kemampuan Berpikir Kreatif Matematis menggunakan pendekatan open-ended salah satu faktornya yaitu terlaksananya dengan baik aktivitas mahasiswa dan guru sesuai dengan langkahlangkah pendekatan open-ended.

\section{E. KESIMPULAN}

Bedasarkan hasil analisis dan pembahasan data penelitian diperoleh beberapa kesimpulan yang terkait dengan hipotesis penelitian yaitu pencapaian Kemampuan Berpikir Kreatif Matematis mahasiswa yang mendapat pembelajaran dengan pendekatan open-ended lebih baik dari pada mahasiswa yang mendapat pembelajaran ekspositori dan peningkatan Kemampuan Berpikir Kreatif Matematis mahasiswa yang mendapat pembelajaran dengan pendekatan open-ended lebih baik dari pada mahasiswa yang mendapat pembelajaran ekspositori.

\section{F. REFERENSI}

Evans, J.R. (2009). Creative Thinking in the Decision and Management Sciences. USA: South-Western Publishing Co.

Hassoubah, I.Z. (2004). Cara Berpikir Kritis dan Kreatif. Bandung: Nuansa.

Hashimoto, Y. (2007). The Significance of an Open-Ended Approach, dalam J. P. Becker dan S.Simada (Ed.). The OpenEnded Approach: A New Proposal For Teaching Mathematics, Virginia: National Council of teachers of mathematics.

Mahmudi, A. (2015). Mengembangkan Soal Terbuka (Open-Ended Problem) dalam Pembelajaran Matematika, Makalah dipresentasikan pada seminar nasional matematika, Pendidikan Matematika FMIPA UNY.

Mina, E. (2009). Pengaruh Pembelajaran Matematika dengan Pendekatan OpenEnded terhadap Kemampuan Berpikir Kreatif Matematik Siswa SMA Bandung. Bandung: Tesis SPS UPI: Tidak diterbitkan.

Ruseffendi, E.T. (2008). Dasar-dasar penelitian pendidikan \& bidang non-eksakta lainnya. Bandung : Tarsito. 
Shimada, S. (2007). The Significance of an Open-Ended Approach, dalam J. P. Becker dan S.Simada (Ed.). The Open Ended Approach: A New Proposal For Teaching Mathematics, Virginia: National Council of teachers of mathematics.

Sugiyono. (2008). Metode penelitian pendidikan. Bandung: Alfabeta.

Suherman dkk., (2001). Strategi pembelajaran matematika kontemporer.Bandung: JICA UPI.

Swada, T., (2007). The Significance of an Open-Ended Approach, dalam J. P. Becker dan S.Simada (Ed.). The Open-Ended Approach: A New Proposal For Teaching Mathematics, Virginia: National Council of teachers of mathematics.

Trianto, (2011). Mendesain Model Pembelajaran InovatifProgresif: Konsep, Landasan, dan Implementasinya Pada Kurikulum Tingkat Satuan Pendidikan, Jakarta: Kencana.

Wahyudin. (2007). Kemampuan Guru Matematika, Calon Guru Matematik, dan Siswa dalam Mata Pelajaran Matematika. Bandung: Disertasi PPS IKIP Bandung: Tidak diterbitkan.

Wijaya, A. (2012). Pendidikan Matematika Realistik, Yogyakarta: Graha Ilmu.

Williams, F. (2007). Creativity Assessment Packet. Bufallo: D.O.K. 